\title{
Pengaruh Pengungkapan Corporate Social Responsibility terhadap Nilai Perusahaan pada Indeks Saham LQ45
}

\author{
Influence of Corporate Social Resposibility Disclosure toward Corporate Value of LQ45 Stock Index
}

\author{
Gusfarini Fauziah $^{1 *}$, Abdul Kohar Irwanto ${ }^{2 *}$ dan Muhammad Syamsun ${ }^{2 *}$
}

${ }^{1}$ Program Magister Manajemen Sekolah Pascasarjana Institut Pertanian Bogor

${ }^{2}$ Departemen Manajemen, Fakultas Ekonomi dan Manajemen, Institut Pertanian Bogor

"Jl. Kamper, Kampus IPB Darmaga, Bogor 16680

\begin{abstract}
ABSTRAK
Pengungkapan Corporate Social Resposibility (CSR) di Indonesia masih rendah karena masih bersifat sukarela. Pengungkapan CSR diharapkan meningkatkan pandangan positif terhadap perusahaan dan menarik minat investor untuk berinvestasi. Penelitian ini bertujuan: (1) Menganalisis pengaruh pengungkapan CSR terhadap kinerja finansial perusahaan pada indeks saham LQ45 (2) Menganalisis pengaruh pengungkapan CSR terhadap kinerja saham perusahaan pada indeks saham LQ45 dan (3) Menganalisis pengaruh kinerja finansial terhadap kinerja saham perusahaan pada indeks saham LQ45. Penelitian ini menggunakan data laporan tahunan dan laporan keuangan perusahaan contoh penelitian tahun 2013. Pengujian hubungan pengaruh CSR terhadap nilai perusahaan menggunakan Structural Equation Modelling (SEM) Hasil penelitian menunjukkan indikator valid sebagai alat ukur konstruk CSR pada indeks saham LQ45 adalah indikator lingkungan, dan masyarakat, dimana indikator ekonomi, Hak Asasi Manusia (HAM), sosial dan tanggung jawab produk tidak valid. Indikator kinerja finansial yang valid sebagai alat ukur konstruk adalah Return On Assets (ROA) sedangkan Debt to Assets Ratio (DAR), Debt to Equity Ratio (DER), Net Profit Margin (NPM) dan Return On Equity (ROE) tidak valid sebagai alat ukur konstruk. Indikator Price to Book Value (PBV) valid sebagai alat ukur konstruk kinerja saham tetapi Earning Per Share (EPS) tidak valid. Dari hasil pengujian hipotesis terlihat CSR tidak berpengaruh nyata terhadap kinerja finansial dan berhubungan negatif, Pengungkapan CSR tidak berpengaruh nyata terhadap kinerja saham dan berhubungan negatif. Tetapi kinerja finansial berpengaruh nyata terhadap kinerja saham dan berhubungan positif.
\end{abstract}

Kata kunci: corporate social responsibilty, indeks saham LQ45, nilai perusahaan

\section{ABSTRACT}

CSR disclosure in Indonesia were still low and voluntary. CSR disclosure is expected to increase positive image of the company and attract investors to invest. This study aims: (1) analyze the effect of CSR disclosure toward corporate financial performance of LQ45 stock index (2) analyze the effect of CSR disclosure toward corporate stock performance of LQ45 stock index and (3) analyze the effect of financial performance toward corporate stock performance of LQ45 stock index. This study used the annual report and financial report of the sample companies on 2013. Test of relationship influences of CSR disclosure toward corporate value were measured by Structural Equation Modelling (SEM). The results of this study showed valid indicators as a measurement construct of CSR disclosure in the LQ45 stock index were environment and society but economic, Human Rights (HAM), social and product responsibility indicators were invalid. Valid indicators of financial performance as a measurement constructs were ROA but DER, DAR, NPM, and ROE were invalid. While PBV was valid as a measure of stock performance construct but EPS were invalid. The results of hypothesis testing explained CSR disclosure were not

\footnotetext{
$\left.{ }^{*}\right)$ Korespondensi:

Jl. Kamper, Kampus IPB Darmaga, Bogor 16680; email: gusfarinifauziah@gmail.com
} 
significant effect on the finansial performance and had negatively related. CSR disclosure were not significant effect on the stock performance and had negatively related. However financial performance were significant effect on the stock performance and had positively related.

Key words: corporate social responsibility, corporate value, LQ45 stock index

\section{PENDAHULUAN}

Salah satu bentuk tanggungjawab perusahaan terhadap stakeholder adalah pelaksanaan Corporate Social Responsibility (CSR). Pelaksanaan CSR oleh perusahaan diharapkan para stakeholder memiliki pandangan positif terhadap perusahaan dan menarik minat investor untuk menanamkan modalnya pada perusahaan tersebut. CSR didasari oleh beberapa teori yaitu teori stakeholder, teori kontrak sosial, teori legitimasi, dan teori persinyalan. Berdasarkan sebuah survei global yang dilakukan oleh The Economist Intelligence Unit didapatkan 88 persen eksekutif senior dan investor dari berbagai organisasi menjadikan CSR sebagai pertimbangan utama dalam pengambilan keputusan (Barus \& Maksum, 2011).

Salah satu standar pengungkapan CSR pada laporan tahunan yang diterima secara luas adalah Global Reporting Initiative (GRI) report. Aktivitas pengungkapan CSR pada perusahaan di Indonesia masih tergolong rendah, dikarenakan pengungkapan CSR masih bersifat sukarela. Berikut perkembangan Jumlah Laporan Sustainability di Indonesia seperti diperlihatkan pada Gambar 1.

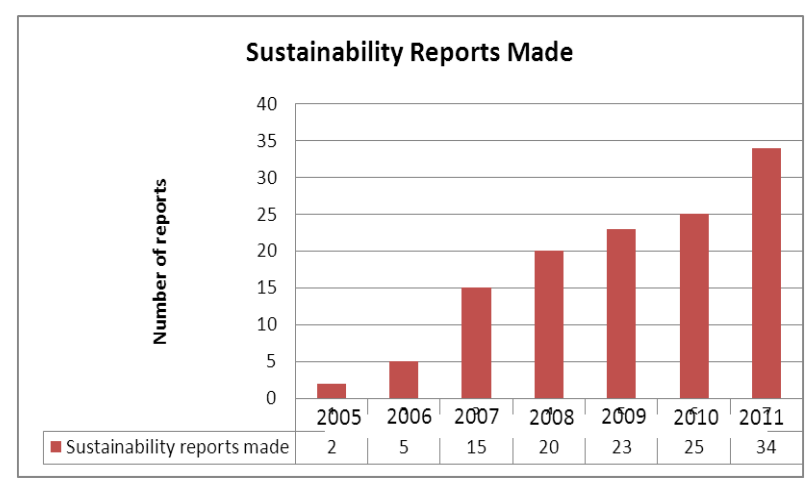

Sumber : National Center for Sustainability Reporting (2014)

Gambar 1. Jumlah laporan sustainability di Indonesia

Dari Gambar 2 terlihat pertumbuhan IHSG dan Indeks saham LQ45 di Bursa Efek Indonesia masih berfluktuatif dan cenderung turun pada tahun 2013. Laju Pertumbuhan Rata-rata (LPR) IHSG adalah sebesar 17,59\%, sedangkan LPR indeks saham LQ45 adalah sebesar $19,67 \%$. Berdasarkan nilai LPR tersebut dapat dikatakan bahwa pertumbuhan indeks LQ45 lebih tinggi dibandingkan IHSG. Artinya perusahaan yang masuk dalam indeks saham LQ45 adalah perusahaan yang memiliki pertumbuhan yang tinggi. Perusahaan yang masuk ke dalam indeks saham LQ45 harus mampu meningkatkan citra positif sehingga menarik minat investor yang mana berdampak pada kinerja saham perusahaan yang semakin tinggi. Namun berdasarkan hasil dari beberapa penelitian mengenai hubungan pengungkapan CSR dengan kinerja finansial perusahaan, diketahui terjadi ketidakkonsistenan mengenai hubungan atau pengaruh pengungkapan CSR pada laporan tahunan terhadap kinerja finansial perusahaan. Sebagian penelitian menemukan terdapat pengaruh nyata pengungkapan CSR pada laporan tahunan perusahaan terhadap nilai perusahaan, akan tetapi sebagian penelitian menyatakan tidak terdapat pengaruh nyata.

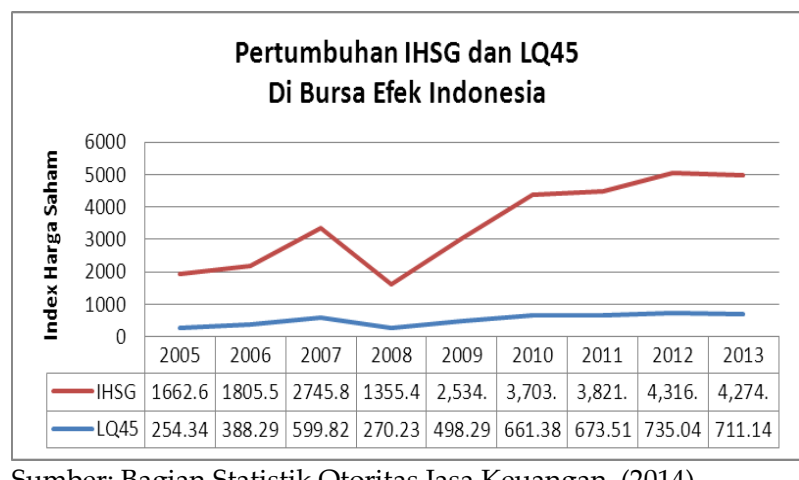

Sumber: Bagian Statistik Otoritas Jasa Keuangan, (2014)

Gambar 2. Pertumbuhan IHSG dan indeks LQ45 di Bursa Efek Indonesia

Berdasarkan latar belakang permasalahan yang telah diuraikan tersebut peneliti tertarik untuk melakukan penelitian mengenai pengaruh pengungkapan CSR terhadap nilai perusahaan yang masuk ke dalam indeks saham LQ45. Nilai perusahaan yang dimaksud dapat dilihat dari kinerja finansial dan kinerja saham perusahaan.

Tujuan penelitian adalah: (1) Menganalisis pengaruh pengungkapan CSR terhadap kinerja finansial perusahaan pada indeks saham LQ45; (2) Menganalisis pengaruh pengungkapan CSR terhadap kinerja saham perusahaan pada indeks saham LQ45; (3) Menganalisis pengaruh kinerja finansial terhadap kinerja saham perusahaan pada indeks saham LQ45. 


\section{METODE PENELITIAN}

Kerangka pemikiran teoritis penelitian dapat dilihat pada Gambar 3. Penerapan CSR diharapkan mampu meningkatkan nilai perusahaan yang tercermin dari peningkatan kinerja finansial dan kinerja saham perusahaan. CSR diungkapkan perusahaan melalui laporan tahunan perusahaan. Penelitian ini menggunakan standar pengungkapan GRI G4 dengan indikator ekonomi, lingkungan, sosial, HAM, masyarakat dan tanggungjawab produk. Pengaruh pengungkapan CSR terhadap nilai perusahaan yang dapat terlihat dari kinerja finansial dan kinerja saham perusahaan. Kinerja finansial perusahaan dapat dilihat melalui rasio-rasio keuangan Debt to Equity Ratio (DER), Debt to Assets Ratio (DAR), Return on Assets (ROA), Return on Equity (ROE) dan Net Profit Margin (NPM). Sedangkan kinerja saham perusahaan dapat dilihat dari nilai Price to Book Value (PBV) dan Earning Per Share (EPS).

Hipotesis penelitian yang diajukan dalam penelitian ini adalah sebagai berikut:

$\mathrm{H}_{1}$ : Pengungkapan Corporate Social Responsibility (CSR) berpengaruh nyata terhadap Kinerja Finansial (KF) perusahaan contoh penelitian.

$\mathrm{H}_{2}$ : Pengungkapan Corporate Social Responsibility (CSR) berpengaruh nyata terhadap Kinerja Saham (KS) perusahaan contoh penelitian.

$\mathrm{H}_{3}$ : Kinerja Finansial (KF) berpengaruh nyata terhadap Kinerja Saham (KS) perusahaan contoh penelitian.

Data dalam penelitian ini merupakan data sekunder, yaitu data kuantitatif dan kualitatif dari beberapa perusahaan pada indeks saham LQ45 yang diperoleh dari instansi atau lembaga yang berkaitan dan telah dipublikasikan. Data diperoleh dari berbagai sumber seperti laporan tahunan dan laporan keuangan perusahaan pada tahun 2013.

Penelitian ini menggunakan metode analisis Struktural Equation Modeling (SEM) dengan software Smart PLS dan menggunakan Microsoft Excel 2010. Pemilihan contoh penelitian didasarkan metode purposive sampling. Contoh penelitian dapat dilihat pada Tabel 1.

\section{HASIL DAN PEMBAHASAN}

\section{Hasil Perhitungan KF dan KS Perusahaan}

Berdasarkan hasil penelitian diketahui bahwa terdapat dua perusahaan yang memperoleh DAR di atas 1, yaitu Bumi Resources $(1,04)$ dan
Unilever (1,21) yang merupakan perusahaan dengan DAR terbesar. Hal ini berarti total hutang Unilever dibandingkan dengan aset terbesar dibanding seluruh perusahaan contoh. Sedangkan nilai DAR paling kecil terdapat pada perusahaan Kalbe Farma (0,04). Terdapat satu perusahaan yang memiliki nilai DER negatif, yaitu perusahaan Bumi Resources. Jika dilihat dari seluruh nilai indikator yang dimiliki oleh perusahaan Bumi Resources diketahui bahwa laba bersih dan kinerja saham bernilai negatif. Sedangkan nilai DER terbesar dimiliki oleh Bank Mandiri $(7,26)$, yang artinya Bank Mandiri memiliki ketergantungan hutang paling besar untuk membiayai modalnya.

Tabel 1. Contoh perusahaan indeks saham LQ45 periode 2009-2013

\begin{tabular}{|c|c|c|}
\hline No & Nama Perusahaan & $\begin{array}{l}\text { Kode } \\
\text { Perusahaan }\end{array}$ \\
\hline 1 & Astra Agro Lestari Tbk & AALI \\
\hline 2 & Adaro Energy Tbk & ADRO \\
\hline 3 & Aneka Tambang (Persero) Tbk & ANTM \\
\hline 4 & Astra International Tbk & ASII \\
\hline 5 & Alam Sutera Realty Tbk & ASRI \\
\hline 6 & Bank Central Asia Tbk & BBCA \\
\hline 7 & Bank Negara Indonesia (Persero) Tbk & BBNI \\
\hline 8 & Bank Rakyat Indonesia (Persero) Tbk & BBRI \\
\hline 9 & Bank Danamon Tbk & BDMN \\
\hline 10 & Bank Mandiri (Persero) Tbk & BMRI \\
\hline 11 & Bumi Serpong Damai Tbk & BSDE \\
\hline 12 & Bumi Resources Tbk & BUMI \\
\hline 13 & Charoen Pokphand Indonesia Tbk & CPIN \\
\hline 14 & XL Axiata Tbk & EXCL \\
\hline 15 & Gudang Garam Tbk & GGRM \\
\hline 16 & Harum Energy Tbk & HRUM \\
\hline 17 & Indofood CBP Sukses Makmur Tbk & $\mathrm{ICBP}$ \\
\hline 18 & Vale Indonesia Tbk & INCO \\
\hline 19 & Indofood Sukses Makmur Tbk & INDF \\
\hline 20 & Indika Energy Tbk & INDY \\
\hline 21 & Indocement Tunggal Prakasa Tbk & INTP \\
\hline 22 & Indo Tambangraya Megah Tbk & ITMG \\
\hline 23 & Jasa Marga (Persero) Tbk & JSMR \\
\hline 24 & Kalbe Farma Tbk & KLBF \\
\hline 25 & Lippo Karawaci Tbk & LPKR \\
\hline 26 & PP London Sumatera Tbk & LSIP \\
\hline 27 & Perusahaan Gas Negara (Persero) Tbk & PGAS \\
\hline 28 & $\begin{array}{l}\text { Tambang Batubara Bukit Asam } \\
\text { (Persero) Tbk }\end{array}$ & PTBA \\
\hline 29 & Semen Indonesia (Persero) Tbk & SMGR \\
\hline 30 & Telekomunikasi Indonesia (Persero) Tbk & TLKM \\
\hline 31 & United Tractors Tbk & UNTR \\
\hline 32 & Unilever Indonesia Tbk & UNVR \\
\hline
\end{tabular}

Rasio profitabilitas pada indikator ROE, nilai terkecil ada pada perusahaan Indika Energy $(-0,74)$, berarti tingkat pengembalian atas modal pada perusahaan Indika Energy mengalami kerugian. ROE terbesar dimiliki oleh perusahaan Bumi Resources $(217,89)$ yang berarti tingkat 


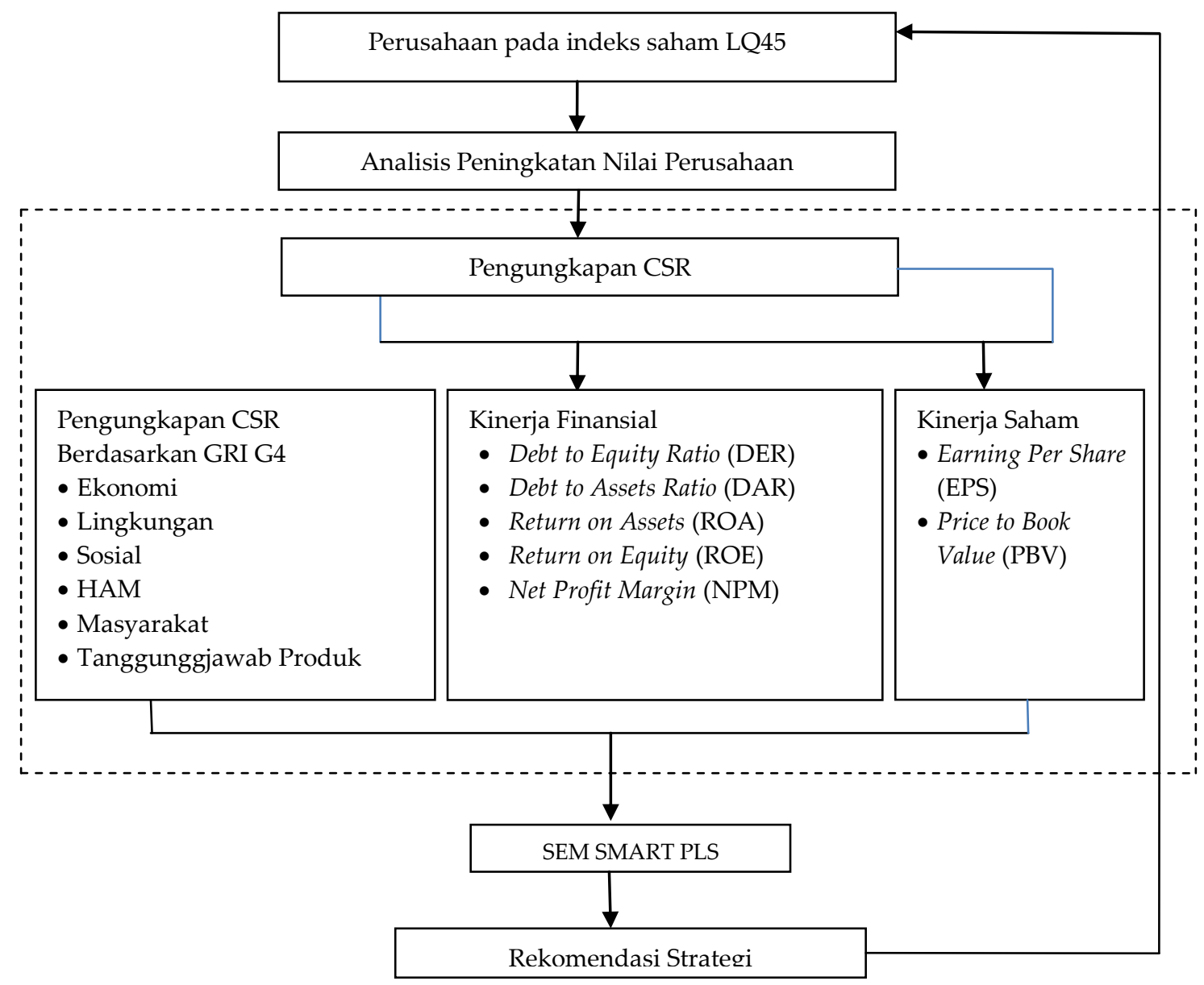

Gambar 3. Kerangka pemikiran teoritis

pengembalian atas ekuitas Bumi Resources terbesar diantara perusahaan contoh. Hal ini diduga karena tidak adanya hutang BUMI pada pihak luar (DER negatif). Tingkat pengembalian atas aset (ROA) terendah dimiliki oleh BUMI yang bernilai negatif $(-9,42)$. ROA tertinggi terdapat pada perusahaan Unilever $(71,51)$. Aset Unilever mampu memberikan tingkat pengembalian tertinggi. Laba bersih (NPM) terendah diperoleh oleh BUMI $(-18,61)$ dan tertinggi diraih oleh BSDE $(50,61)$. Kemampuan manajemen Bumi Serpong Damai (BSDE) dalam mencetak laba bersih yang tinggi merupakan daya tarik bagi investor dalam memutuskan berinvestasi pada perusahaan ini. Sebagai perusahaan properti, BSDE juga sebaiknya meningkatkan image perusahaan dengan melaksanakan CSR dan mengungkapkan CSR ke dalam laporan tahunan (annual report) perusahaan.

Price to Book Value (PBV) bernilai negatif pada BUMI $(-29,54)$, hal ini berarti harga pasar saham terhadap nilai buku saham sangat kecil. PBV tertinggi terdapat pada perusahaan CPIN $(5,75)$ yang menggambarkan bahwa harga pasar saham terhadap nilai buku saham Charoen Pokphand Indonesia paling tinggi dari seluruh perusahaan indeks LQ45 yang masuk pada periode 2009-2013. PBV yang tinggi menggambarkan kinerja finansial baik bagi perusahaan.

Kinerja saham yang ditunjukkan oleh indikator Earning Per Share (EPS) terendah diperoleh oleh BUMI $(-359,72)$. Hal ini berarti kinerja saham BUMI sangat buruk, karena kerugian yang dialami oleh perusahaan tersebut pada tahun 2013 (NPM negatif). Kinerja saham terbesar dicapai oleh GGRM $(2249,76)$, ini menunjukkan kemampuan perusahaan Gudang Garam paling baik dalam meningkatkan kinerja sahamnya. Kinerja saham yang baik akan mendorong minat investor untuk berinvestasi.

\section{Analisa Model Awal}

Peubah laten CSR memiliki enam indikator yaitu ekonomi, HAM, lingkungan, masyarakat, sosial dan tanggung jawab produk. Peubah laten KF menggunakan lima indikator yaitu DAR, DER, NPM, ROA dan ROE. Peubah laten KS memiliki dua indikator yaitu PBV dan EPS. Model hubungan antara peubah laten dan indikator pada penelitian ini ditunjukkan oleh model reflektif dapat dilihat pada Gambar 4. 


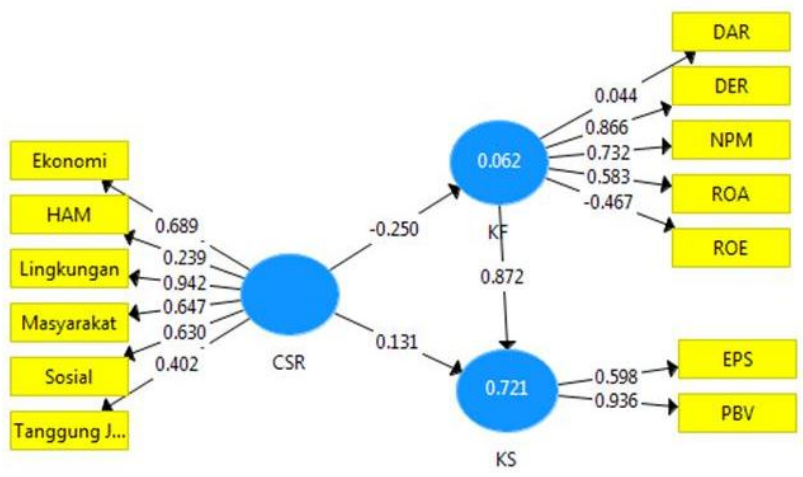

Gambar 4. Model awal diagram Path SEM

Perbaikan model dilakukan dengan melihat koefisien peubah laten dengan indikatornya. Jika nilai loading factornya di bawah 0,7 (Ghozali, 2008) harus dikeluarkan dari dari model. Analisis pada model awal yang terlihat pada Gambar 4 dilakukan dengan mengeluarkan peubah yang memiliki nilai loading factor paling rendah dibandingkan peubah lainnya dan selanjutnya melakukan pengujian ulang. Tahap pertama dilakukan dengan mengeluarkan indikator $\operatorname{ROE}(-0,467)$ pada peubah laten KF. Proses ini berlangsung satu persatu dengan mengeluarkan nilai loading factor di bawah 0,7 dari setiap model baru yang dihasilkan dari proses iterasi sebelumnya sampai ditemukan suatu model dimana tidak ada lagi nilai loading factor di bawah 0,7 seperti ditunjukkan pada Gambar 4 .

Setelah melakukan tahap pengeluaran terhadap model awal maka terbentuk model akhir seperti pada Gambar 5. Dari hasil analisis model akhir pada Gambar 5, nilai loading factor pada peubah laten CSR adalah lingkungan $(0,879)$, masyarakat $(0,903)$ telah memiliki nilai lebih dari 0,7 (Ghozali, 2008) yang menyatakan indikator tersebut valid dalam mengukur konstruk. Hal tersebut dapat dikatakan bahwa terlaksananya CSR yang baik adalah ketika kedua indikator tersebut dapat dilakukan dengan optimal. Indikator masyarakat memiliki interelasi yang paling besar dalam merefleksikan variabel CSR dengan nilai loading factor 0,903. Perusahaan diharapkan selalu memperhatikan masyarakat di sekitar daerah operasionalnya.

Indikator yang valid mencerminkan peubah laten KF seperti pada Gambar 5 adalah ROA (1). ROA adalah kemampuan perusahaan dalam menghasilkan laba dari aset yang dimiliki. Perusahaan yang memiliki pengembalian atas aset yang tinggi mencerminkan kinerja finansial perusahaan yang baik. Investor menilai kinerja perusahaan dari kemampuan perusahaan dalam mengelola aset yang dimiliki.

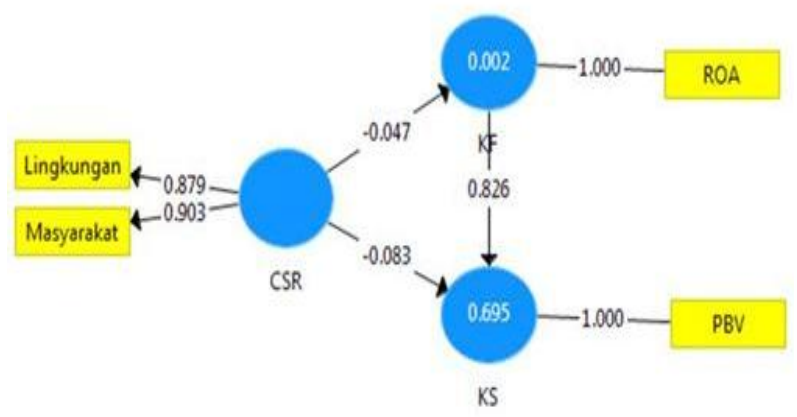

Gambar 5. Model akhir diagram Path SEM

Pada peubah laten KS, indikator PBV (bernilai 1) menunjukkan nilai valid dalam mencerminkan kinerja saham. Kinerja saham dapat dilihat dari return saham. PBV dapat memprediksi tingkat return saham. Semakin tinggi nilai PBV menunjukkan perusahaan semakin dipercaya artinya nilai perusahaan menjadi lebih tinggi untuk memberikan return saham pada investor. Hasil penelitian ini sesuai dengan penelitian Damayanti (2009) yang menyatakan bahwa rasio PBV memiliki hubungan yang nyata dengan return saham.

\section{Evaluasi Model Pengukuran Mode Reflektif}

Yamin dan Kurniawan (2011) mengatakan bahwa evaluasi model pengukuran adalah evaluasi hubungan antar konstruk laten dengan indikatornya. Penelitian ini menggunakan model outer-reflective. Analisis model outer-reflective dapat dilakukan dua tahap, yaitu evaluasi terhadap convergent validity dan discriminant validity. Convergent validity dapat dievaluasi dengan tiga tahap, yaitu validitas setiap indikator yang sudah dilakukan pada pembahasan sebelumnya (melihat nilai loading factor), Average Variance Extracted atau AVE. dan composite reliability (reliabilitas) atau reliabilitas konstruk.

Tabel 2. Nilai outer loadings

\begin{tabular}{llll}
\hline & CSR & KF & KS \\
\hline Lingkungan & 0,879 & & \\
Masyarakat & 0,903 & & \\
ROA & & 1 & 1 \\
PBV & & & \\
\hline
\end{tabular}

Tabel 2 menunjukkan nilai outer loading pada indikator lingkungan, masyarakat, ROA dan PBV memiliki nilai lebih dari 0,7 (Ghozali 2008). Hal ini diartikan indikator-indikator tersebut memiliki hubungan valid dan baik sebagai indikator yang mengukur konstruk. 
Tabel 3. Overview dari model akhir

\begin{tabular}{lllll}
\hline & AVE & $\begin{array}{l}\text { Composite } \\
\text { Reliability }\end{array}$ & $\begin{array}{l}\text { Cronbach's } \\
\text { Alpha }\end{array}$ & $\begin{array}{l}\text { R } \\
\text { Square }\end{array}$ \\
\hline CSR & 0,794 & 0,885 & 0,741 & \\
KF & 1 & 1 & 1 & 0,002 \\
KS & 1 & 1 & 1 & 0,695 \\
\hline
\end{tabular}

Pengukuran validitas menggunakan AVE menggambarkan besarnya varian atau keragaman variabel manifes yang dapat dikandung oleh peubah laten. Dalam penelitian ini nilai AVE untuk masing-masing peubah dapat dilihat pada Tabel 3, nilai AVE peubah laten CSR 0,794, kinerja finansial 1 dan, kinerja saham 1 , dimana nilai tersebut sudah diatas nilai standar 0,5 artinya indikator valid. Pengukuran validitas dengan menggunakan Composite Reliability (CR) digunakan untuk melihat internal consistency reliability. Nilai CR pada penelitian ini adalah CSR $(0,885), \mathrm{KF}(1)$ dan KS (1). Nilai tersebut telah di atas nilai standar 0,7. Hal ini menunjukkan konsistensi pada peubah yang diukur. Selain $\mathrm{CR}$, kriteria pengukuran untuk melihat internal consistency reliability adalah nilai Cronbach's Alpha (CA). Standar CA valid adalah 0,7 . Pada penelitian ini nilai CA peubah CSR $(0,784)$, KF (1) dan KS (1), artinya terdapat konsitensi pada peubah yang diukur.

Analisis validitas diskriminan kriteria cross loading digunakan untuk mengetahui apakah konstruk memiliki diskrimInan yang memadai dengan cara membandingkan nilai loading pada konstruk yang dituju harus lebih besar jika dibandingkan dengan nilai loading konstruk lainnya (Armien dan Friedrich, 2012). Hasil analisis yang disajikan pada Tabel 4 menunjukkan korelasi indikator dengan masing-masing peubah latennya memiliki korelasi lebih tinggi dibandingkan korelasi dengan indikator pada peubah laten lainnya.

\section{Evaluasi Model Struktural}

Model struktural atau inner model menggambarkan hubungan diantara peubah laten, yaitu hubungan langsung antara CSR dan Kinerja Finansial (KF), CSR dan Kinerja Saham (KS) serta Kinerja Finansial (KF) dan Kinerja Saham (KS). Kriteria $R$-square $\left(\mathrm{R}^{2}\right)$ dari peubah laten endogen menunjukkan seberapa besar keragaman peubah endogen yang dapat dijelaskan oleh peubah eksogen.

Peubah endogen pada penelitian ini adalah kinerja finansial dan kinerja saham. Hasil peneliti- an ini menunjukkan bahwa peubah endogen kinerja finansial dipengaruhi oleh peubah eksogen CSR dengan nilai $R^{2} 0,002$. Hal tersebut dapat diartikan bahwa peubah kinerja finansial dapat dijelaskan oleh peubah CSR dengan keragaman 0,2 persen sisanya $99,8 \%$ dijelaskan oleh peubah lain yang tidak termasuk dalam penelitian ini. Nilai $R^{2}$ ini menurut Chin dalam Yamin dan Kurniawan (2011) dikategorikan ke dalam kelompok lemah. Nilai $R^{2}$ rendah dapat menduga implementasi CSR yang dilakukan perusahaan belum sepenuhnya kesadaran dari internal stake-holder, akan tetapi masih sekedar trend dan infor-masi yang harus diungkapkan untuk mematuhi peraturan yang berlaku. Hal ini dapat dilihat dari laporan tahunan pada pengungkapan CSR, per-usahaan tidak secara lengkap dalam mengungkap-kan CSR nya. Kategori yang diungkapkan sebatas isu yang sedang berkembang saat ini seperti ekonomi, lingkungan dan sumbangan kepada masyarakat sekitar yang terkena dampak. Selain itu diindikasikan bahwa perusahaan masih ragu dalam melaksanakan atau mengungkapkan CSR, karena berasumsi bahwa CSR dalam pelaksanaannya akan mengurangi laba dan dividen bagi pemegang saham dan menganggap CSR tidak mempengaruhi peningkatan kemampuan operasional perusahaan.

Tabel 4. Analisis validitas diskriminan kriteria cross loading

\begin{tabular}{llll}
\hline & CSR & KF & KS \\
\hline Lingkungan & $\mathbf{0 , 8 7 9}$ & 0,070 & $-0,144$ \\
Masyarakat & $\mathbf{0 , 9 0 3}$ & $-0,142$ & $-0,076$ \\
ROA & $-0,047$ & $\mathbf{1 , 0 0 0}$ & 0,829 \\
PBV & $-0,121$ & 0,829 & $\mathbf{1 , 0 0 0}$ \\
\hline
\end{tabular}

Sumber: Data Primer Diolah (2015)

Pada peubah kinerja saham yang dipengaruhi oleh CSR dan kinerja finansial menghasilkan nilai $\mathrm{R}^{2}$ sebesar 0,695 , hal ini dapat diartikan bahwa peubah kinerja saham dapat dijelaskan oleh peubah CSR dan kinerja finansial dengan keragaman $69,5 \%$, sedangkan sisanya 30,5 persen dijelaskan oleh variabel lain yang tidak termasuk dalam penelitian ini. Nilai $R$-square ini tergolong subtansial artinya kinerja saham sangat dipengaruhi oleh pengungkapan informasi CSR dan kinerja finansial.

Hasil perhitungan data pada Tabel 5 menunjukkan nilai hasil bootstrap koefisien path dengan nilai $p$ value $<0,05$. Jika nilai [t hitung] $>\mathrm{t}-$ tabel $(1,96)$, maka tolak $\mathrm{H}_{0}$ dan terima $\mathrm{H}_{1}$. Hasil 
pengolahan data pada penelitian ini menunjukkan bahwa t hitung CSR terhadap KF 0,157< t-tabel $(1,96)$, maka terima $\mathrm{H}_{0}$ dan tolak $\mathrm{H}_{1}$. Pada hipotesis pertama dapat dikatakan bahwa pengungkapan CSR tidak berpengaruh nyata terhadap Kinerja Finansial perusahaan contoh penelitian. Hal ini tidak sesuai dengan penelitian Prieto et al (2014) menyatakan CSR memiliki pengaruh sangat baik dalam meningkatkan reputasi dan kinerja finansial perusahaan, karena dengan pelaksanaan CSR yang sesuai, masyarakat akan merasakan kehadiran perusahaan dalam memperbaiki kehidupan ke arah positif sehingga akan memperkuat reputasi yang baik dari pandangan konsumen dan kinerja finansial perusahaan akan meningkat. Jika dilihat dari nilai koefisiennya, pengaruh tersebut bersifat negatif (dilihat dari nilai original sample pada Tabel 5) yaitu $-0,047$. Hasil penelitian ini menggambarkan bahwa pengungkapan CSR tidak mampu meningkatkan kinerja finansial perusahaan contoh penelitian. Hal ini diduga karena adanya kelebihan investasi dan juga pelaksanaan CSR yang kurang pengawasan. Pelaksanaan CSR yang kurang pengawasan menyebabkan adanya penyalahgunaan dana yang digunakan untuk perilaku yang oportunis oleh para pelaksana program CSR tersebut.

Tabel 5. Nilai hasil bootstrap koefisien path

\begin{tabular}{lcccc}
\hline & $\begin{array}{l}\text { Original } \\
\text { Sample } \\
(\mathrm{O})\end{array}$ & $\begin{array}{l}\text { Sample } \\
\text { Mean } \\
(\mathrm{M})\end{array}$ & $\begin{array}{l}\text { Standar } \\
\text { Error } \\
(\text { STERR) }\end{array}$ & $\begin{array}{c}\text { T Statistics } \\
(\text { | O/STERRI })\end{array}$ \\
\hline CSR -> KF & $-0,047$ & 0,031 & 0,299 & 0,157 \\
CSR -> KS & $-0,083$ & $-0,122$ & 0,172 & 0,481 \\
KF -> KS & 0,826 & 0,836 & 0,116 & 7,122 \\
\hline
\end{tabular}

$\mid$ t hitung $|>|$ t tabel $\mid \rightarrow$ nyata

Sumber: Data Primer Diolah (2015)

Pada hipotesis kedua, hasil pengujian pengaruh CSR terhadap kinerja saham menunjukkan [t hitung 0,481] <t-tabel (1,96), artinya pengungkapan CSR memiliki pengaruh tidak nyata terhadap kinerja saham dengan nilai koefisien yang bernilai positif $(-0,083)$, dapat dikatakan bahwa pengungkapan CSR tidak mampu meningkatkan kinerja saham perusahaan. Hal ini kurang sesuai dengan teori persinyalan dari Jogiyanto dalam Tomas (2011) yang menyatakan CSR secara nyata berpengaruh terhadap harga saham, dan mengatakan bahwa informasi yang dipublikasikan sebagai suatu pengumuman akan memberikan sinyal bagi investor dalam pengambilan keputusan investasi.
Menurut Sayekti dan Wondabio (2008) investor tidak cukup yakin dengan informasi sukarela seperti pengungkapan CSR yang diungkapkan manajemen, sehingga investor tidak menggunakan informasi tersebut sebagai dasar untuk pengambilan keputusan. Pelaksanaan program CSR perusahaan sebaiknya dilakukan dengan optimal sehingga memberikan dampak positif pada stakeholder sehingga citra perusahaan akan meningkat. Selain itu pengungkapan CSR pada laporan tahunan perusahaan sebaiknya mengikuti standar yang telah ditetapkan oleh GRI sehingga investor dengan mudah melihat sejauh mana perusahaan telah melakukan CSR.

Hasil pengujian hipotesis ketiga menunjukkan bahwa kinerja finansial memiliki pengaruh nyata ([t hitung 7,122] $<\mathrm{t}$ table 1,96) terhadap kinerja saham. Jika dilihat dari nilai koefisien yang bernilai positif $(0,826)$, dapar dikatakan bahwa kinerja finansial perusahaan mampu meningkatkan kinerja saham. Hal ini sesuai dengan penelitian yang dilakukan oleh Hamdani (2013) mengenai pengaruh pengungkapan CSR terhadap kinerja finansial dan harga saham perusahaan LQ45 periode 2008-2012 yang menunjukkan bahwa kinerja finansial berpengaruh secara nyata terhadap harga saham. Namun penelitian ini tidak sesuai dengan penelitian yang dilakukan oleh oleh Geovanni (2013) terhadap harga saham perusahaan pertambangan yang terdaftar di bursa efek Indonesia periode 2009-2011 yang menunjukkan bahwa kinerja finansial tidak berpengaruh secara nyata terhadap harga saham.

\section{KESIMPULAN}

Berdasarkan hasil penelitian disimpulkan bahwa pengungkapan CSR memiliki pengaruh tidak nyata terhadap kinerja finansial pada perusahaan yang diteliti dan nilai koefisien negatif. Hal ini menunjukkan kegiatan CSR memiliki pengaruh tetapi tidak mampu meningkatkan kinerja finansial perusahaan atau membuat kinerja finansial perusahaan lebih baik.

Pengungkapan CSR memiliki pengaruh yang tidak nyata terhadap kinerja saham pada perusahaan yang diteliti dan memiliki hubungan yang bersifat negatif dengan kinerja saham artinya pengungkapan CSR tidak akan meningkatkan kinerja saham perusahaan. Hal ini mengindikasikan jika investor dalam membeli saham pada perusahaan yang masuk ke dalam indeks saham LQ45 tidak meletakkan prioritas penilaian pada 
aspek CSR dalam pengambilan keputusan investasinya.

Kinerja finansial berpengaruh nyata terhadap kinerja saham pada perusahaan yang diteliti dan memiliki hubungan bersifat positif. Hal ini menunjukkan jika kondisi kinerja finansial perusahaan berpengaruh terhadap keputusan investor dalam membeli saham perusahaan. Dari hasil penelitian mengindikasikan jika kondisi kinerja saham dan keputusan investor dalam berinvestasi melalui pembelian saham secara nyata terpengaruh dari kinerja finansial perusahaan.

\section{DAFTAR PUSTAKA}

Barus, R \& Maksum, A. 2011. Analisis Pengungkapan Informasi Corporate Social Responsibility (CSR) dan Pengaruhnya terhadap Harga Saham. Seminar Nasional Kontribusi Dunia Pendidikan Ekonomi, Manajemen, dan Akuntansi dalam Penguatan Perekonomian Bangsa.

BEI. 2014. IDX LQ45 Februari 2014. [Internet]. [diunduh 2014 April 25]. Tersedia pada: http://www.idx.co.id/Portals/0/StaticData/Pu blication/LQ45.

Cahyaningsih. 2011. The effect of leverage, priceto-book-value, and size withcorporate social responsibility disclosure as an intervening variable. The2nd International Research Symposium in Service Management. Yogyakarta, Indonesia, 26-30 July 2011.

Damayanti, G. 2009. Pengaruh Rasio Keuangan Terhadap Return Saham pada Perusahaan Manufaktur yang tergabung dalam Indeks LQ45 di Bursa Efek Indonesia. Potensio Vo. 11 No. 1 Juli 2009. STIE.YPPI Rembang.

Damodaran, A. 2002. Investment Valuation, Tools, and Technic for Determiningthe Value of Any Asset. Singapore. John Willey \& Sons, Inc.

Geovanni, PA. 2013. Pengaruh Pengungkapan Corporate Social Responsibility Terhadap Harga Saham (Studi Empiris pada Perusahaan Pertambangan yang Terdaftar Di Bursa Efek Indonesia Periode 2009-2011)

Ghozali, I. 2008. Structural Equation Modeling Metode Alternatif dengan Partial Least Square (PLS). Semarang. Badan Penerbit Undip.

Global Reporting Initiative. 2014. GRI G4 [Internet]. [diunduh 2014 Juni 15]. Tersedia pada:https://www.globalreporting.org/standards/g4
Gray, RJ, M. David, M \& Sinclair, C. Donald. 2001. Social and Environmental Disclosure and Corporate Characteristic: A Research Note and Extension. Journal of Business Finance and Accounting, 28(3): 327-356.

Hamdani, M. 2013. Analisis Hubungan Pengungkapan Corporate Social Responsibility (CSR) Terhadap Kinerja Keuangan dan Harga Saham Pada Perusahaan LQ45. Bogor. Institut Pertanian Bogor.

Haniffa, R.M. dan T.E. Cooke. 2005. The Impact of culture and Governance on Corporate Social Reporting. Journal of Accounting and Public Policy 24. [Internet]. [Diunduh 2014 April 1]. Tersedia pada: http://econ-papers.repec.org/ article/eeejappol/default24.htm.

Hidayansyah, PF. 2014. Pengaruh Pengung-kapan Corporate Social Responsibility Ter-hadap Kinerja Keuangan dan Harga Saham Pada Perusahaan Sektor Properti di Bursa Efek Indonesia. Bogor. Institut Pertanian Bogor.

IkatanAkuntansi Indonesia. 2009. Standar Laporan Keuangan. [Internet] [Diunduh 2014 April 1]. Tersedia pada: http://www.iaiglobal.or.id.

NCSR. 2014. Report of The Judges 2011. [Internet]. [Diunduh 2014 April 1]. Tersedia pada: http://www.ncsr-id.org/wp-content/uploads/ 2012/01/Report-of-the-Judges-2011.pdf.

Otorisasi Jasa Keuangan. 2014. Statistik Pasar Modal. [Internet]. [Diunduh 2014 April 1]. Tersedia pada : http://www.ojk.go.id/datastatistik-pasar-modal.

Putra, R dan Astika. 2012. Pengaruh Corporate Social Responsibility Pada Price To Book Value Dengan Corporate Governance Sebagai Variabel Moderasi. Bali. Universitas Udayana.

Priote C Leon, Phipps Simone T, Addae Y Isaac. 2014. Is Wal-Mart A Social Enterprise? An Exploration Of The Relationship Between Corporate Reputation, Corporate Social Responsibility \& Financial Performance. Academy of Strategic Management Journal, Volume 13, Number 2.

Sayekti, Y. dan Wondabio, L. S. 2007. Pengaruh CSR Disclosure Terhadap Earning Response Coefficient. Simposium Nasional Akuntansi (26-28 Juli 2007). Program Ilmu Akuntansi FEUI.

Tomas S dan Dzajuli A. 2011. Pengaruh Pengungkapan Corporate Social Responsibili-ty Dan Kinerja Keuangan Perusahaan Terhadap Return Saham Perusahaan di Indeks LQ45 Bursa Efek Indonesia Periode 2008-2010. 
William. 2012. Pengaruh Pengungkapan Corporate Social Responsibility Berdasarkan Pedoman Global Reporting Initiative Terhadap Nilai Perusahaan. Jakarta. Universitas Indonesia.
Yamin, Sofyan dan Kurniawan, Heri. 2009. Structural Equation Modeling (belajar lebih mudah teknik analisis data kuesioner dengan Lisrel-PLS). Jakarta. Salemba Infotek 2011. Generasi Baru Mengolah Data dengan Partial Least Square Path Modeling. Jakarta. Salemba Infotek. 